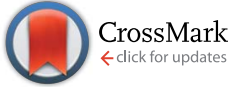

Cite this: J. Mater. Chem. B, 2015, 3, 475

Received 30th September 2014 Accepted 10th November 2014

DOI: $10.1039 / c 4 t b 01627 \mathrm{k}$

www.rsc.org/MaterialsB

\section{Metastable oxidation states of tetrathiafulvalenes on the surface of liposomes $\uparrow$}

\author{
U. Kauscher, ${ }^{a}$ K. Bartels, ${ }^{\text {ab }}$ I. Schrader, ${ }^{\text {b V. A. Azov }}{ }^{\star b}$ and B. J. Ravoo*a \\ Redox-active liposomes are prepared by the incorporation of tetrathiafulvalene-cholesterol conjugate 1 in \\ phospholipid vesicles. The oxidation of tetrathiafulvalene (TTF) on the surface of the liposomes in aqueous \\ solution is monitored by UV-vis spectroscopy. It is shown that metastable $\left(\mathrm{TTF}^{+\cdot}\right)_{2} \pi$-dimers of the mono- \\ oxidized cation radical are formed due to the high local concentration of TTF groups in the lipid membrane. \\ These dimers can be further stabilized by the addition of cucurbit[8]uril or by reduction of the lateral \\ mobility in the membrane by variation of the lipid composition.
}

\section{Introduction}

Liposomes are artificially prepared analogues of biological membrane vesicles, which are spherical supramolecular nanocontainers composed of a closed bilayer membrane shell surrounding an internal aqueous compartment. ${ }^{1}$ Liposomes can be thought of as minimal models of biological cells or cell organelles, such as mitochondria, lysosomes, and vacuoles thin-walled vessels composed of membrane surrounded by and encapsulating water. Thus, liposomes have served as versatile model objects to study various aspects of cellular chemistry: vesicle adhesion and fusion, ${ }^{2}$ transmembrane ion transport ${ }^{3}$ and electron transfer, ${ }^{4}$ as well as reactivity and molecular recognition on cell surfaces. ${ }^{5}$

Redox reactions of organic functional groups on membranes play an important role in various cellular processes, representing another important aspect of cellular activity. One of the most prominent examples is the electron transport chain in eukaryotic cells. ${ }^{6}$ The electron transport chain drives ATP synthesis and takes place in the inner membrane of mitochondria and includes oxidation ${ }^{7}$ of $\mathrm{NADH}$ to $\mathrm{NAD}^{+}$and the electron-carrier function of lipophilic ubiquinone ${ }^{8}$ (Coenzyme $\mathrm{Q}_{10}$ ). Another prime example is photosynthesis, ${ }^{9}$ in which organisms utilize light to oxidize water and reduce carbon dioxide to carbohydrates in a cascade of redox reactions, which starts upon excitation of photosynthetic complexes ${ }^{\mathbf{1 0}}$ bound to thylakoid membranes of chloroplasts or cyanobacteria. Moreover, redox processes with reactive oxygen species were found to play a central role in cell homeostasis, signalling, and

${ }^{a}$ Organisch Chemisches Institut, Westfälische Wilhelms-Universität Münster, Corrensstr.40, 48143 Münster, Germany.E-mail: b.j.ravoo@uni-muenster.de

${ }^{b}$ Institut für Organische Chemie, Universität Bremen, Leobener Str. NW2C, 28359 Bremen, Germany. E-mail: vazov@uni-bremen.de

$\dagger$ Electronic supplementary information (ESI) available: Analytical data for $\mathbf{1}$ including NMR, MS, UV-vis spectra and CV as well as additional DLS and UV-vis data. See DOI: $10.1039 / \mathrm{c} 4 \mathrm{tb} 01627 \mathrm{k}$ apoptosis. ${ }^{11}$ Quite surprisingly, redox chemistry of artificial vesicles with organic redox-active centres is barely described in the literature and limited to membrane-bound viologen ${ }^{12}$ and ferrocene $^{13}$ derivatives.

In this article we describe the preparation and characterization of redox-active liposomes containing tetrathiafulvalene (TTF, Fig. 1). TTF $^{\mathbf{1 4 , 1 5}}$ possesses an electron-rich non-aromatic $14-\pi$-electron system. Stepwise oxidation of TTF leads first to the formation of a stable radical cation, $\mathrm{TTF}^{+}{ }^{\bullet}$, and finally to a dication, $\mathrm{TTF}^{2+}$, and occurs at low oxidation potentials easily achieved using mild oxidation reagents. Due to their excellent electron-donating properties, TTF found use in the field of organic electronics. ${ }^{16}$ More recently, TTF were employed in different areas of supramolecular chemistry as redox triggers ${ }^{\mathbf{1 7}}$ of switching processes in various types of supramolecular systems, ${ }^{18}$ such as redox controllable molecular machines, ${ }^{19}$ organogels, ${ }^{20}$ and liquid crystals. ${ }^{21}$ Nevertheless, there is only a very limited number of publications dedicated to the investigation of TTF-modified amphiphiles and their aggregates in aqueous solution. ${ }^{22}$

Herein, we report preparation of the cholesterol-TTF conjugate 1 (Fig. 2) and its incorporation in redox-active liposomes. ${ }^{23}$ The amphiphile $\mathbf{1}$ (Chol-TTF) consists of a redox-active TTF group, which is connected via a hydrophilic oligoethyleneglycol spacer to a cholesterol moiety that serves as a membrane anchor. Although the TTF group is lipophilic in the non-oxidized form and is likely to reside inside the lipid membrane, it should become much more exposed to the aqueous medium upon oxidation. Chol-TTF 1 was prepared in

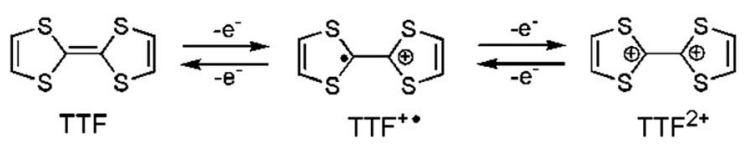

Fig. 1 Reversible stepwise oxidation of tetrathiafulvalene (TTF). 


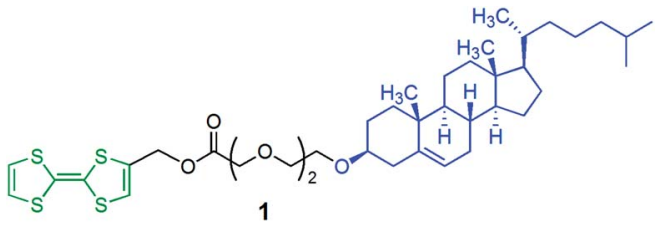

Fig. 2 Redox-active amphiphile Chol-TTF 1. Redox-active TTF is shown in green and cholesterol anchor in blue.

several steps from commercially available cholesterol and tetrathiafulvalene.

Simple mixing of 1 with phospholipids leads to the formation of liposomes with TTF groups immobilized close to the membrane surface. We observed that the addition of $\mathrm{Fe}\left(\mathrm{ClO}_{4}\right)_{3}$ leads to the oxidation of TTF to the radical cation $\mathrm{TTF}^{+\cdot}$, which is stabilized by $\left(\mathrm{TTF}^{+\bullet}\right)_{2}$ dimer formation, and then to the $\mathrm{TTF}^{2+}$ dication. We measured the kinetics of the oxidation of TTF in dioleoylphosphatidyl choline (DOPC) and dipalmitoylphosphatidyl choline (DPPC) liposomes as well as the remarkable effect of the supramolecular host cucurbit[8]uril ( $\mathrm{CB}[8])$ on the stabilization of $\left(\mathrm{TTF}^{+\cdot}\right)_{2}$.

\section{Experimental section}

\section{Materials and methods}

4-(Hydroxymethyl)tetrathiafulvalene ${ }^{24} 2$ was prepared from commercially available (TCI) tetrathiafulvalene, and $[2-[2-[2-$ [(3ß)-cholest-5-en-3-yloxy]ethoxy]ethoxy]ethoxy]-acetic $\operatorname{acid}^{25} 3$ was synthesized from cholest-5-en-3 $\beta$-tosylate ${ }^{26}$ as described before. Cholesterol-TTF conjugate $\mathbf{1}$ was prepared from compounds $\mathbf{2}$ and $\mathbf{3}$ in two steps (Scheme 1). All reactions were carried out under atmosphere of dry $\mathrm{N}_{2}$. NMR spectra were recorded using Bruker Avance DPX-200, and Bruker Avance WB360 spectrometers. Chemical shifts $(\delta)$ are reported in parts per million (ppm) downfield from tetramethylsilane, residual solvent signals (7.26 ppm for ${ }^{1} \mathrm{H}, 77.0 \mathrm{ppm}$ for ${ }^{13} \mathrm{C}$ in $\mathrm{CDCl}_{3}$ ) were used as references. ${ }^{1} \mathrm{H}$ NMR coupling constants $(J)$ are reported in Hertz $(\mathrm{Hz})$ and multiplicity is indicated as follows: $\mathrm{s}$ (singlet), d (doublet), t (triplet). Mass spectra were measured on Bruker MicroTOF electrospray ionization (ESI) spectrometer. Observed isotopic patterns of the $[\mathrm{M}]^{+},[\mathrm{M}+\mathrm{Na}]^{+}$, and $[\mathrm{M}+\mathrm{K}]^{+}$ ions of the product were fully consistent with the calculated ones. $R_{\mathrm{f}}$ value was determined using $0.2 \mathrm{~mm}$ silica gel F-254 TLC cards. Column chromatography (FC) was carried out using 230440 mesh (particle size $36-70 \mu \mathrm{m}$ ) silica gel.

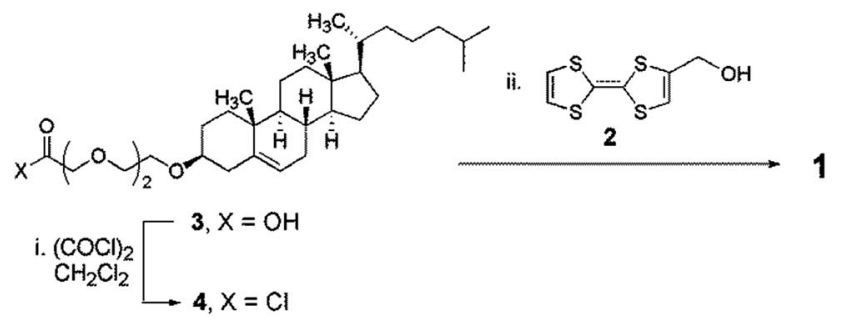

Scheme 1 Synthesis of redox-active amphiphile Chol-TTF 1.

\section{Synthesis}

[2-[2-[2-[(3ß)-Cholest-5-en-3-yloxy]ethoxy]ethoxy]ethoxy]-acetic acid chloride 4. [2-[2-[2-[(3 $\beta)$-Cholest-5-en-3-yloxy]ethoxy] ethoxy]ethoxy]-acetic acid $3(240 \mathrm{mg}, 0.42 \mathrm{mmol})$ was dissolved in absolute $\mathrm{CH}_{2} \mathrm{Cl}_{2}, 2-3$ drops of DMF were added to a solution, and it was cooled to $0{ }^{\circ} \mathrm{C}$. Oxalyl chloride $(0.15 \mathrm{~mL}, 1.75 \mathrm{mmol})$ was added dropwise, the reaction mixture was allowed to warm to room temperature and stirred for additional $3 \mathrm{~h}$, then the solvent was evaporated to dryness, and the product was dried under high vacuum. Reaction afforded $250 \mathrm{mg}(0.42 \mathrm{mmol}$, $100 \%$ ) of the product as colourless syrup, which was used in the next step without further purification.

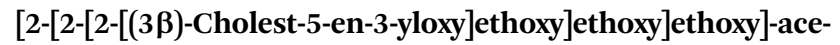
tic acid, [2-(1,3-dithiol-2-ylidene)-1,3-dithiol-4-yl]methyl ester 1. 4-(Hydroxymethyl)tetrathiafulvalene $2(123 \mathrm{mg}, 0.52 \mathrm{mmol})$ and pyridine $(0.32 \mathrm{~mL})$ were dissolved in abs. THF $(10 \mathrm{~mL})$ and cooled to $0{ }^{\circ} \mathrm{C}$. After that a solution of acid chloride $4(360 \mathrm{mg}$, $0.60 \mathrm{mmol})$ in abs. THF $(10 \mathrm{~mL})$ was added dropwise. The reaction mixture was allowed to warm to room temperature and stirred overnight, then poured into excess of water and extracted with $\mathrm{CH}_{2} \mathrm{Cl}_{2}(c a .50 \mathrm{~mL})$. The organic phase was washed with $1 \mathrm{M} \mathrm{HCl}(20 \mathrm{~mL})$, saturated $\mathrm{NaHCO}_{3}$ solution $(20 \mathrm{~mL})$, and brine $(50 \mathrm{~mL})$, dried $\left(\mathrm{Na}_{2} \mathrm{SO}_{4}\right)$, and evaporated to dryness. The crude product was purified by column chromatography $\left(\mathrm{SiO}_{2}, \mathrm{CH}_{2} \mathrm{Cl}_{2} / \mathrm{EtOAc} 10: 2\right)$ affording $109 \mathrm{mg}$ $(0.14 \mathrm{mmol}, 27 \%)$ of the product 1 as yellow syrup that crystallized slowly. $R_{\mathrm{f}}: 0.36\left(\mathrm{CH}_{2} \mathrm{Cl}_{2} / \mathrm{EtOAc}, 10: 2\right) .{ }^{1} \mathrm{H}$ NMR $(360$ $\left.\mathrm{MHz}, \mathrm{CDCl}_{3}\right): \delta 0.67(\mathrm{~s}, 3 \mathrm{H}), 0.85-0.87(\mathrm{~m}, 6 \mathrm{H}), 0.90-1.54$ $(\mathrm{m}, 27 \mathrm{H}), 1.77-2.03(\mathrm{~m}, 5 \mathrm{H}), 2.17-2.24(\mathrm{~m}, 1 \mathrm{H}), 2.34-2.39$ $(\mathrm{m}, 1 \mathrm{H}), 3.13-3.22(\mathrm{~m}, 1 \mathrm{H}), 3.63(\mathrm{~s}, 4 \mathrm{H}), 3.66(\mathrm{~s}, 4 \mathrm{H}), 3.68-3.76$ $(\mathrm{m}, 4 \mathrm{H}), 4.20(\mathrm{~s}, 2 \mathrm{H}), 4.88(\mathrm{~d}, J=0.9 \mathrm{~Hz}, 2 \mathrm{H}), 5.33-5.34(\mathrm{~m}, 1 \mathrm{H})$, $6.31(\mathrm{~s}, 2 \mathrm{H}), 6.36(\mathrm{t}, J=0.9 \mathrm{~Hz}, 1 \mathrm{H}) .{ }^{13} \mathrm{C} \mathrm{NMR}\left(50 \mathrm{MHz}, \mathrm{CDCl}_{3}\right)$ : $\delta$ 11.8, 18.6, 19.3, 21.0, 22.5, 22.8, 23.7, 24.2, 27.9, 28.1, 28.3, $31.79,31.84,35.7,36.1,36.8,37.1,39.0,39.4,39.7,42.2,50.1$, 56.0, 56.7, 60.8, 67.2, 68.3, $70.5(3 \times), 70.8,70.9,79.4,108.8$, $112.0,118.9,119.0,119.9,121.4,130.4,140.8,169.9$. UV-Vis (MeCN): $\lambda_{\max }(\varepsilon) 314 \mathrm{~nm}\left(13700 \mathrm{~L} \mathrm{~mol}^{-1} \mathrm{~cm}^{-1}\right), 360 \mathrm{sh}(2500 \mathrm{~L}$ $\left.\mathrm{mol}^{-1} \mathrm{~cm}^{-1}\right)$. MS $\left(\mathrm{ESI}^{+}\right): \mathrm{m} / z 792[\mathrm{M}]^{+}, 815[\mathrm{M}+\mathrm{Na}]^{+}, 831$ $[\mathrm{M}+\mathrm{K}]^{+}$. HRMS $\left(\mathrm{ESI}^{+}\right): m / z[\mathrm{M}]^{+\cdot}$ calcd. for $\mathrm{C}_{42} \mathrm{H}_{64} \mathrm{O}_{6} \mathrm{~S}_{4} \mathrm{Na}^{+}$: 815.3478; found 815.3457. CV (vs. SCE, MeCN): $E_{1 / 2}^{\text {ox1 }}=0.36 \mathrm{~V}$, $E_{1 / 2}^{0 \times 2}=0.71 \mathrm{~V}$

\section{Cyclic voltammetry}

Cyclic voltammetry (CV) was performed using a computer controlled HEKA PG390 potentiostat in a three electrode single compartment cell $(2.5 \mathrm{~mL})$ with a platinum disk working electrode (diameter of $1.5 \mathrm{~mm}$ ) and a platinum wire used as a counter electrode. A non-aqueous $\mathrm{Ag} / \mathrm{Ag}^{+}$secondary electrode, containing $0.1 \mathrm{M} \mathrm{Bu}_{4} \mathrm{NClO}_{4}$ (TBAP) + $0.01 \mathrm{M} \mathrm{AgNO}_{3}$ in acetonitrile (MeCN), was used as the reference electrode. Samples for CV were dissolved to a concentration of $1 \times 10^{-3}$ $\mathrm{M}$ in dry degassed MeCN, containing $0.1 \mathrm{M}$ TBAP as supporting electrolyte. Ferrocene $(\mathrm{Fc})$ was used as an electrochemical reference with the potential $E_{1 / 2}^{\text {ox }}=0.38 \mathrm{~V} v s$. saturated calomel electrode (SCE) for the $\mathrm{Fc} / \mathrm{Fc}^{+}$couple in 0.1 $\mathrm{M} \mathrm{TBAP} / \mathrm{CH}_{2} \mathrm{Cl}_{2} \cdot{ }^{27}$ 


\section{Preparation and characterization of liposomes}

DOPC and DPPC were purchased from Sigma Aldrich and dissolved in $\mathrm{CHCl}_{3}(1 \mathrm{mM})$. Unilamellar liposomes were prepared by hydration (using pure water) of a film containing a mixture of a phospholipid and Chol-TTF 1 followed by extrusion with a Liposofast manual extruder through a polycarbonate membrane with a pore size of $100 \mathrm{~nm}$. DOPC liposomes were extruded at room temperature, whereas DPPC liposomes were extruded at $50{ }^{\circ} \mathrm{C}$. Dynamic light scattering (DLS) measurements were performed on a Zetasizer Nanoseries Nano-ZS of the company Malvern Instruments. UV-vis measurements were performed on a Jasco V650 double beam spectrophotometer in a $1 \mathrm{~cm}$ path length quartz optical cell.

\section{Results and discussion}

Chol-TTF 1 was obtained as bright yellow viscous syrup slowly crystallizing upon standing. Compound $\mathbf{1}$ displays very good solubility in non-polar organic solvents, which allowed its easy spectroscopic and electrochemical characterization. The electrochemical behaviour of $\mathbf{1}$ is typical for TTF derivatives with two reversible oxidation potentials at $E_{1 / 2}^{1}=0.36 \mathrm{~V}$ and $E_{1 / 2}^{2}=0.71 \mathrm{~V}$ in MeCN vs. SCE (Fig. S5 $\dagger$ ). Stepwise oxidation of 1 in MeCN was achieved using $\mathrm{Fe}\left(\mathrm{ClO}_{4}\right)_{3} / \mathrm{MeCN}$ as an oxidizing agent. Upon addition of $\mathrm{Fe}\left(\mathrm{ClO}_{4}\right)_{3} / \mathrm{MeCN}$ to $0.06 \mathrm{mM}$ MeCN solution of CholTTF, all three oxidation states of 1 were observed and characterised using UV-Vis spectroscopy (Fig. S6†). In the non-oxidized state, 1 shows major absorption signal at $314 \mathrm{~nm}$, as well as a shoulder at ca. $360 \mathrm{~nm}$. Upon addition of $1 \mathrm{eq}$. of $\mathrm{Fe}\left(\mathrm{ClO}_{4}\right)_{3}$ signals at $438 \mathrm{~nm}$ and $584 \mathrm{~nm}$ assigned to $\mathrm{TTF}^{+\cdot}$ become dominant. After addition of an excess of $\mathrm{Fe}\left(\mathrm{ClO}_{4}\right)_{3}$, a single absorption maximum at $380 \mathrm{~nm}$, typical to $\mathrm{TTF}^{2+}$, is observed. ${ }^{28}$ Chol-TTF 1 could be reduced to its initial state in MeCN using an excess of ascorbic acid as a reduction agent (Fig. S10†).

Redox-active liposomes were obtained by the hydration of a lipid film containing a mixture of Chol-TTF 1 and DOPC to afford the final aqueous solution with $0.06 \mathrm{mM}$ Chol-TTF and $0.14 \mathrm{mM}$ DOPC total concentrations. Small unilamellar liposomes with an average diameter of $80-100 \mathrm{~nm}$ were formed using extrusion through a porous polycarbonate membrane. The liposome size was routinely controlled using DLS. The redox behaviour of the liposomes was monitored using UV-vis spectroscopy. First, measurements were performed before and during the addition of $\mathrm{Fe}\left(\mathrm{ClO}_{4}\right)_{3}$ solution as oxidizing agent (Fig. 3). After each addition of an aliquot of $\mathrm{Fe}^{3+}$, an incubation period of several min was observed before the absorption reached stable value, serving as an indication that neutral TTF groups are embedded in the lipid membrane rather than exposed to the surrounding solution and not well accessible to the oxidation agent.

The major absorption signal of non-oxidized TTF at $303 \mathrm{~nm}$ is dominant before the addition of $\mathrm{Fe}\left(\mathrm{ClO}_{4}\right)_{3}$ and persists at low concentrations of $\mathrm{Fe}\left(\mathrm{ClO}_{4}\right)_{3}$. With increasing amounts of oxidizing agent, the signal at $303 \mathrm{~nm}$ decreases until it disappears completely. Instead, signals at $390 \mathrm{~nm}, 520 \mathrm{~nm}$ and $775 \mathrm{~nm}$ appear, which, in turn, decline upon further addition of oxidizing agent.

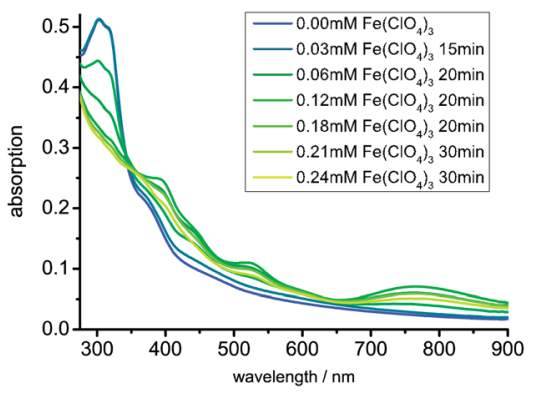

Fig. 3 Oxidative titration of TTF on the surface of DOPC liposomes with $\mathrm{Fe}\left(\mathrm{ClO}_{4}\right)_{3}$ monitored by UV-vis-spectroscopy. After each addition of an aliquot of $\mathrm{Fe}\left(\mathrm{ClO}_{4}\right)_{3}$, absorption was measured after the indicated time period. [DOPC] $=0.14 \mathrm{mM}$, [Chol-TTF 1] $=0.06 \mathrm{mM},\left[\mathrm{Fe}\left(\mathrm{ClO}_{4}\right)_{3}\right]$ $=0.03-0.24 \mathrm{mM}$

The unexpected appearance of the rather strong absorption band at $775 \mathrm{~nm}$ was attributed by us to the formation of $\left(\mathrm{TTF}^{\cdot+}\right)_{2}$ dimers. It should be emphasized that this is a metastable oxidation state of TTF that is not usually observed at room temperature in dilute solution. Dimer formation of the TTF radical cation is common in the solid state and can be observed at low temperatures in a concentrated TTF solution, ${ }^{29}$ but only a few examples of the characterization of $\left(\mathrm{TTF}^{+\bullet}\right)_{2}$ at room temperature in a dilute solution are known up to date. They are limited to bis-TTF derivatives with two closely-aligned TTF units, such as bis-TTF molecular clips ${ }^{30}$ and TTF-substituted calix[4]arenes, ${ }^{31}$ to supramolecular architectures in which dimers $\left(\mathrm{TTF}^{+\bullet}\right)_{2}$ are stabilized in the framework of [3]cantenane, ${ }^{32}$ and to inclusion complex of two $\mathrm{TTF}^{+} \cdot$ radical cations within the cavity of cucubit[8]uril..$^{33}$ In all these examples, dimer stabilization was achieved by localization of two TTF groups in close proximity. In this case, we observe stabilization of $\left(\mathrm{TTF}^{+\bullet}\right)_{2}$ dimers on a liposome surface in a dilute aqueous solution ([Chol-TTF 1] $=0.06 \mathrm{mM})$. Such unusual stabilization can be explained by the fact that, although the overall concentration of $\mathbf{1}$ in aqueous solution is very low, its local concentration in the membrane is high: every third molecule within a membrane is a TTF derivative. It is reasonable to assume that upon oxidation such a high local concentration of TTF groups on membrane surface leads to the formation of stable $\left(\mathrm{TTF}^{+}\right)_{2}$ radical dimers (Fig. 4).

To investigate the oxidation kinetics of TTF on the liposome surface, we measured the absorbance at $775 \mathrm{~nm}$, characteristic to the $\left(\mathrm{TTF}^{\cdot+}\right)_{2}$ dimers, over time for liposomes consisting of $0.14 \mathrm{mM}$ DOPC and $0.06 \mathrm{mM}$ Chol-TTF (Fig. 5, left panel). Increasing amounts of oxidation agent were added. All profiles show a fast increase (i.e. minute time scale) after addition of oxidizing agent up to a maximum followed by a slower decrease (i.e. hour time scale). The maximum absorbance obviously represents the maximum concentration of $\left(\mathrm{TTF}^{\cdot+}\right)_{2}$ dimers that is transiently formed and is dependent on the amount of oxidizing agent added. With time the amount of $\left(\mathrm{TTF}^{\cdot+}\right)_{2}$ decreases, since the radical cation is further oxidized and ultimately $\mathrm{TTF}^{2+}$ is formed. The kinetic profile can thus be interpreted as a transient formation of the intermediate radical 


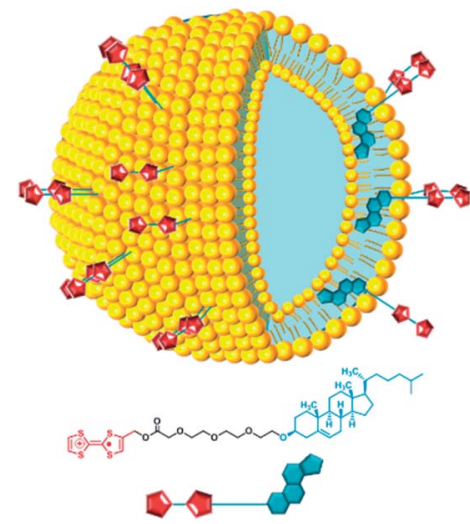

Fig. 4 Schematic representation of the stabilized $\left(\mathrm{TTF}^{\cdot+}\right)_{2}$ dimers formed by the oxidation of Chol-TTF 1 on the surface of liposomes.

cation with a fast oxidation from TTF to $\mathrm{TTF}^{+}$and rather slow oxidation from $\mathrm{TTF}^{+}$to $\mathrm{TTF}^{2+}$. The DLS data taken before and after the measurement show that the liposomes are not affected by the oxidation process: the average size remains constant, and hence the liposomes do not aggregate or disintegrate (Fig. S7†). Moreover, reversibility of the TTF oxidation was demonstrated using ascorbic acid as a reducing reagent. The addition of ascorbic acid to liposomes with fully oxidized TTF units led to gradual build up and disappearance of the same absorption bands at $775 \mathrm{~nm}$, indicating the reverse process, which included the reduction of $\mathrm{TTF}^{2+}$ to $\mathrm{TTF}^{\cdot+}$ with dimer formation and then to neutral TTF (Fig. S11†).

Strikingly, the metastable $\left(\mathrm{TTF}^{*+}\right)_{2}$ dimers can be stabilized by the addition of the supramolecular host $\mathrm{CB}[8]$. The same oxidation experiments were repeated in the presence of 0.03 $\mathrm{mM}$ of $\mathrm{CB}[8]$, which is known to form an inclusion complex with $\left(\mathrm{TTF}^{{ }^{+}}\right)_{2}$ dimers. ${ }^{33}$ Inclusion into $\mathrm{CB}[8]$ stabilizes the $\left(\mathrm{TTF}^{*+}\right)_{2}$ dimer on the liposome surfaces and inhibits oxidation to $\mathrm{TTF}^{2+}$. Indeed, in the presence of $\mathrm{CB}[8]$, the absorption at $775 \mathrm{~nm}$ quickly reaches a plateau and stays constant over time and no further oxidation to $\mathrm{TTF}^{2+}$ occurs even after addition of excess of the oxidation agent (Fig. 5, right panel). The solutions turn slightly pink, affording additional evidence for the formation of stable $\left(\mathrm{TTF}^{\cdot+}\right)_{2}$ dimers. The comparison between absorption profiles with and without $\mathrm{CB}[8]$ (Fig. 5, left panel) shows a fourfold increase in the absorption maxima for the measurements with $\mathrm{CB}[8]$. It can be concluded that the maximum concentration of dimer is much higher in the presence of $\mathrm{CB}[8]$.

Finally, we investigated the oxidation Chol-TTF in DPPC liposomes instead of DOPC liposomes (Fig. 6). Whereas DOPC liposomes have a phase transition below room temperature and thus have highly fluid membranes, DOPC liposomes have a phase transition temperature of $41^{\circ} \mathrm{C}$ and gel-like membranes. Thus, DPPC membranes are expected to inhibit lateral movement of the embedded Chol-TTF-derivatives. In comparison to the experiments with DOPC, the results obtained with DPPC show a slightly slower increase to a maximum concentration of $\left(\mathrm{TTF}^{\circ+}\right)_{2}$ dimer after addition of oxidation agent at $775 \mathrm{~nm}$. However, in contrary to the oxidation on DOPC-liposomes, we obtain a much slower decrease after the maximum is reached, meaning that the oxidation to $\mathrm{TTF}^{2+}$ is significantly slowed down. We assume that the formed dimers are more stable due to decreased membrane fluidity. It should be noted that the maximum of the signal at $775 \mathrm{~nm}$ is significantly lower compared to the same signal obtained for the DOPC liposomes, leading to the conclusion that less dimers are being formed in total. This is to be expected since the decreased movement

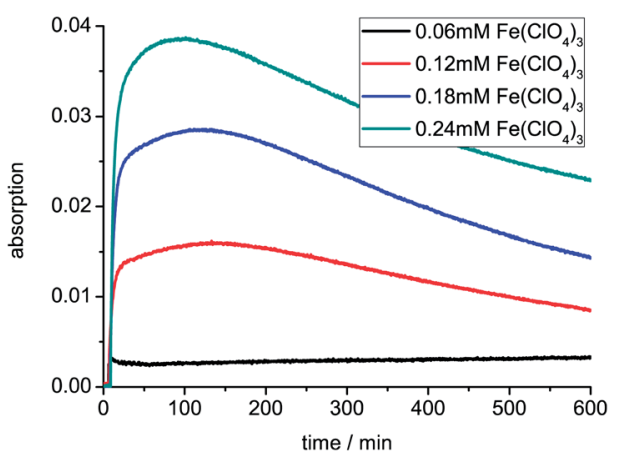

Fig. 6 Oxidation of TTF on DPPC liposomes monitored over time at $775 \mathrm{~nm}$. [DPPC] $=0.14 \mathrm{mM}$, [Chol-TTF 1] $=0.06 \mathrm{mM}$, $\left[\mathrm{Fe}\left(\mathrm{ClO}_{4}\right)_{3}\right]=$ $0.06-0.24 \mathrm{mM}$.
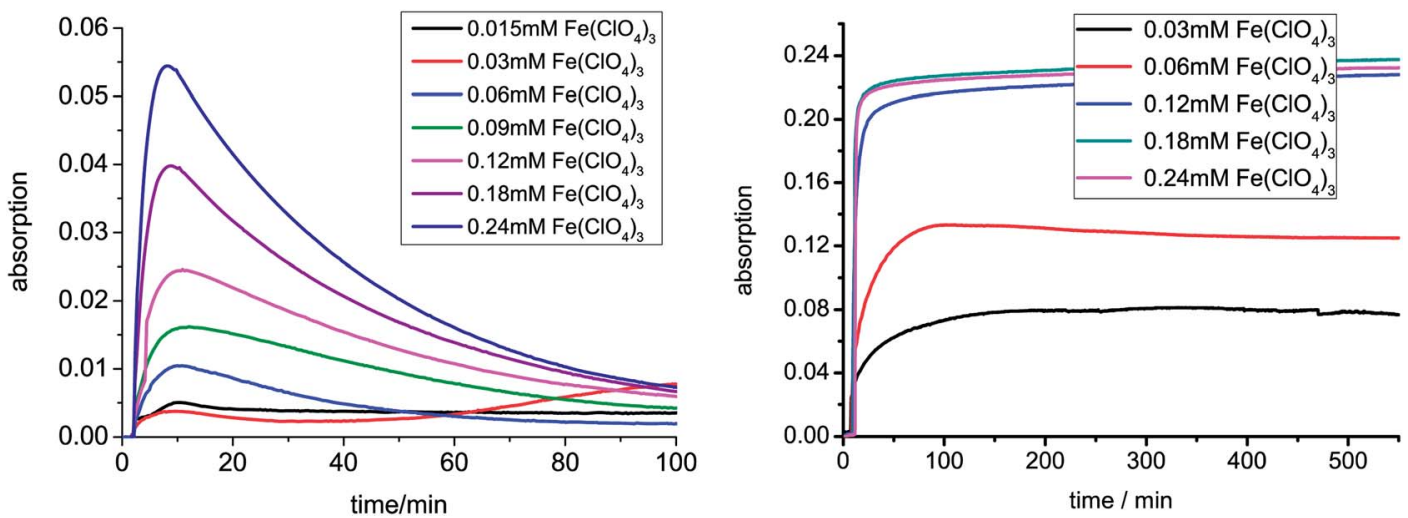

Fig. 5 Oxidation of TTF on the surface of DOPC liposomes monitored over time at $775 \mathrm{~nm}$ without (left panel) and with CB[8] (right panel). $[\mathrm{DOPC}]=0.14 \mathrm{mM},[\mathrm{Chol}-\mathrm{TTF} 1]=0.06 \mathrm{mM},\left[\mathrm{Fe}\left(\mathrm{ClO}_{4}\right)_{3}\right]=0.00-0.24 \mathrm{mM},[\mathrm{CB}[8]]=0.03 \mathrm{mM}$. 
allowed by DPPC makes it harder for monomers to find each other on the membrane. Also in this case, DLS measurements show that the liposomes stay intact after addition of oxidation agent (Fig. S9†).

\section{Conclusions}

In conclusion, we have demonstrated successful incorporation of redox-active cholesterol-TTF conjugates into liposomes in an aqueous solution and have monitored the stepwise oxidation of the TTF moiety into $\mathrm{TTF}^{+\cdot}$ and to $\mathrm{TTF}^{2+}$ on the liposome surface. We identified a remarkable steady-state with fast oxidation from TTF to $\mathrm{TTF}^{+}$and slow oxidation from $\mathrm{TTF}^{+}$and to $\mathrm{TTF}^{2+}$, indicating the formation of stable $\left(\mathrm{TTF}^{\cdot+}\right)_{2}$ dimer at the membrane surface, which are elusive in solution at room temperature. The dimers can be further stabilized by the addition of the supramolecular host $\mathrm{CB}[8]$, which fully inhibits the oxidation of $\mathrm{TTF}^{+}$to $\mathrm{TTF}^{2+}$. We contend that these initial findings demonstrate the relevance of a deeper investigation of redox processes at the surface of biomimetic membranes, including factors such as lateral dynamics and flip-flop, charge transfer across the lipid membrane and/or between vesicles.

\section{Acknowledgements}

This work was supported by COST CM1005 "Supramolecular Chemistry in Water".

\section{Notes and references}

1 D. D. Lasic, Liposomes: from Physics to Application, Elsevier: Amsterdam, 1993.

2 (a) F. M. Menger and K. D. Gabrielson, Angew. Chem., Int. Ed., 1995, 34, 2091-2106; (b) C. M. Paleos, D. Tsiourvas and Z. Sideratou, ChemBioChem, 2011, 12, 510-521.

3 (a) M. J. Pregel, L. Jullien and J.-M. Lehn, Angew. Chem., Int. Ed., 1992, 31, 1637-1640; (b) O. Murillo, S. Watanabe, A. Nakano and G. W. Gokel, J. Am. Chem. Soc., 1995, 117, 7665-7679.

4 J. N. Robinson and D. J. Cole-Hamilton, Chem. Soc. Rev., 1991, 20, 49-94.

5 J. Voskuhl and B. J. Ravoo, Chem. Soc. Rev., 2009, 38, 495505.

6 D. Voet and J. G. Voet, Biochemistry, John Wiley \& Sons, 3rd edn, 2004.

7 N. Pollak, C. Dölle and M. Ziegler, Biochem. J., 2007, 402, 205-218.

8 L. Ernster and G. Dallner, Biochim. Biophys. Acta, 1995, 1271, 195-204.

9 R. E. Blankenship, Molecular Mechanisms of Photosynthesis, Blackwell Science, Oxford, 2002.

10 M. K. Sener, J. D. Olsen, C. N. Hunter and K. Schulten, Proc. Natl. Acad. Sci. U. S. A., 2007, 104, 15723-15728.

11 (a) T. Finkel, Curr. Opin. Chem. Biol., 1998, 10, 248-253; (b) P. D. Ray, B.-W. Huang and Y. Tsuji, Cell. Signalling, 2012, 24, 981-990.
12 E. Baumgartner and J. H. Fuhrhop, Angew. Chem., Int. Ed., 1980, 19, 550-551.

13 K. Wang and G. W. Gokel, J. Phys. Org. Chem., 1997, 10, 323334.

14 TTF Chemistry: Fundamentals and Applications of Tetrathiafulvalene, ed. J. Yamada and T. Sugimoto, Springer Verlag: Heidelberg, 2004.

15 J. L. Segura and N. Martín, Angew. Chem., Int. Ed., 2001, 40, 1372-1409.

16 (a) R. M. Bryce, Adv. Mater., 1999, 11, 11-23; (b) M. Bendikov, F. Wudl and D. F. Perepichka, Chem. Rev., 2004, 104, 48914945.

17 D. Canevet, M. Sallé, G. Zhang, D. Zhang and D. Zhu, Chem. Commun., 2009, 2245-2269.

18 (a) M. R. Bryce, J. Mater. Chem., 2000, 10, 589-598; (b) J. Becher, J. O. Jeppesen and K. Nielsen, Synth. Met., 2003, 133-134, 309-315.

19 (a) A. R. Pease, J. O. Jeppesen, J. F. Stoddart, Y. Luo, C. P. Collier and J. R. Heath, Acc. Chem. Res., 2001, 34, 433-444; (b) N. N. P. Moonen, A. H. Flood, J. M. Fernández and J. F. Stoddart, Top. Curr. Chem., 2005, 262, 99-132.

20 (a) J. Puigmart-Luis, V. Laukhin, A. P. del Pino, J. VidalGancedo, C. Rovira, E. Laukhina and D. B. Amabilino, Angew. Chem., Int. Ed., 2007, 46, 238-241; (b) T. Kitahara, M. Shirakawa, S. Kawano, U. Beginn, N. Fujita and S. Shinkai, J. Am. Chem. Soc., 2005, 127, 14980-14981; (c) C. Wang, Q. Chen, F. Sun, D. Zhang, G. Zhang, Y. Huang, R. Zhao and D. Zhu, J. Am. Chem. Soc., 2010, 132, 3092-3096.

21 T. Yasuda, K. Tanabe, T. Tsuji, K. K. Coti, I. Aprahamian, J. F. Stoddart and T. Kato, Chem. Commun., 2010, 46, 12241226.

22 (a) M. Jørgensen and K. Bechgaard, J. Org. Chem., 1994, 59, 5877-5882; (b) J. Bigot, B. Charleux, G. Cooke, F. Delattre, D. Fournier, J. Lyskawa, L. Sambe, F. Stoffelbach and P. Woisel, J. Am. Chem. Soc., 2010, 132, 10796-10801.

23 For a report on TTF derivatives that form vesicles in organic solvents, see: K. D. Zhang, G. T. Wang, X. Zhao, X. K. Jiang and Z. T. Li, Langmuir, 2010, 26, 6878-6882.

24 J. Garin, J. Orduna, S. Uriel, A. Moore, M. Bryce, S. Wegener, D. Yufit and J. Howard, Synthesis, 1994, 489-493.

25 F. M. Menger and V. A. Azov, J. Am. Chem. Soc., 2000, 122, 6492-6493.

26 J. Biswas, S. K. Mishra, P. Kondaiah and S. Bhattacharya, Org. Biomol. Chem., 2011, 9, 4600-46013.

27 (a) G. Gritzner and J. Kuta, Pure Appl. Chem., 1984, 56, 461466; (b) V. V. Pavlishchuk and A. W. Addison, Inorg. Chim. Acta, 2000, 298, 97-102; (c) N. G. Connely and W. E. Geiger, Chem. Rev., 1996, 96, 877-910.

28 Spectra of TTF, $\mathrm{TTF}^{+}$, and $\mathrm{TTF}^{2+}$ species are consistent with the previously reported ones, see: P. R. Ashton, V. Balzani, J. Becher, A. Credi, M. C. T. Fyfe, G. Mattersteig, S. Menzer, M. B. Nielsen, F. M. Raymo, J. F. Stoddart, M. Venturi and D. J. Williams, J. Am. Chem. Soc., 1999, 121, 3951-3957.

29 S. V. Rosokha and J. K. Kochi, J. Am. Chem. Soc., 2007, 129, 828-838.

30 P. T. Chiang, N. C. Chen, C. C. Lai and S. H. Chiu, Chem.-Eur. J., 2008, 14, 6546-6552. 
31 J. Lyskawa, M. Salle, J. Y. Balandier, F. Le Derf, E. Levillain, M. Allain, P. Viel and S. Palacin, Chem. Commun., 2006, 2233-2235.

32 (a) J. M. Spruell, A. Coskun, D. C. Friedman, R. S. Forgan, A. A. Sarjeant, A. Trabolsi, A. C. Fahrenbach, G. Barin, W. F. Paxton, S. K. Dey, M. A. Olson, D. Benitez, E. Tkatchouk, M. T. Colvin, R. Carmielli, S. T. Caldwell, G. M. Rosair, S. G. Hewage, F. Duclairoir, J. L. Seymour, A. M. Z. Slawin, W. A. Goddard III, M. R. Wasielewski,
G. Cooke and J. F. Stoddart, Nat. Chem., 2010, 2, 870-879; (b) A. Coskun, J. M. Spruell, G. Barin, A. C. Fahrenbach, R. S. Forgan, M. T. Colvin, R. Carmieli, D. Benítez, E. Tkatchouk, D. C. Friedman, A. A. Sarjeant, M. R. Wasielewski, W. A. Goddard III and J. F. Stoddart, J. Am. Chem. Soc., 2011, 133, 4538-4547.

33 A. Y. Ziganshina, Y. H. Ko, W. S. Jeon and K. Kim, Chem. Commun., 2004, 806-807. 